\title{
GENETIC VARIABILITY, CORRELATION AND PATH ANALYSIS FOR YIELD AND YIELD COMPONENTS IN PROMISING RICE (Oryza sativa L.) GENOTYPES
}

\author{
N.S. kishore, T. Srinivas ${ }^{*}$, U. Nagabhushanam, M. Pallavi and Sk. Sameera ${ }^{1}$ \\ Regional Sugarcane and Rice Research Station, Rudrur- 503188, Nizamabad, Telengana, India
}

\begin{abstract}
Seventy three rice varieties were evaluated for their variability with regards to yield and yield components. Estimates of heritability and genetic advance in per cent of mean were also obtained for the above traits. In addition, studies on character associations and path coefficients were also undertaken. The results revealed high variability, heritability and genetic advance in per cent of mean for grain yield while panicle bearing tillers and 1000 grain weight had recorded high heritability coupled with low genetic advance as per cent of mean. Further, yield was observed to be positively associated with panicle bearing tillers and number of filled grains per panicle and these characters were noticed to exert high direct effects on grain yield per plant. High indirect effects of most of the traits were noticed mostly through panicle bearing tillers per hill indicating importance of the trait as selection criteria in crop yield improvement programmes.
\end{abstract}

Keywords: Correlation, Genetic advance, Heritability, Path co-efficients,

Rice, Yield, Yield components.

\section{INTRODUCTION}

Rice is the most consumed cereal grain in the world. It is staple food crop for more than half of the world's human population. Yield enhancement is the major breeding objective in rice breeding programmes and knowledge on the nature and magnitude of the genetic variation governing the inheritance of quantitative characters like yield and its components is essential for effective genetic improvement. A critical analysis of the genetic variability parameters, namely, Genotypic Coefficient of Variability (GCV), Phenotypic Coefficient of Variability (PCV), heritability and genetic advance for different traits of economic importance is a major pre-requisite for any plant breeder to work with crop improvement pogrammes. Further, information on correlation co-efficients between grain yield and

\footnotetext{
* Corresponding author email: $\underline{\text { srinivat68@gmail.com }}$

${ }^{1}$ Research Scholar, Dept. of Genetics and Plant Agricultural College, Mahanandi, Andhra Pradesh, India
}

Received: 05.11.2014 
its component characters is essential for yield improvement, since grain yield in rice is a complex entity and is highly influenced by several component characters. Studies on path co-efficient also provide useful information regarding the direct and indirect effects of different yield component characters on grain yield and thus aid in the

identification of effective selection criteria for effective yield improvement. The present investigation was undertaken in this context to elucidate information on variability, heritability, genetic advance, character associations and path of effect in promising rice genotypes of Acharya N G Ranga Agricultural University, Andhra Pradesh, India.

\section{MATERIALS AND METHODS}

The present investigation was undertaken with 73 pre-release and high yielding rice genotypes developed at different rice research stations of Andhra Pradesh state of India. These genotypes were sown during Kharif 2012 at the wet land farm of Regional Sugarcane and Rice Research station, Rudrur in a randomized block design with three replications. Twenty-five day old seedlings of each genotype were transplanted in twelve rows, each of $3.0 \mathrm{~m}$ length by adopting a spacing of $15 \mathrm{~cm}$ between rows and $15 \mathrm{~cm}$ between plants within the rows. All recommended practices were followed to raise a healthy crop. Observations were recorded for grain yield and yield component characters, namely, days to 50 per cent flowering, plant height, panicle bearing tillers/hill, panicle length, number of filled grains per panicle and 1000 grain weight. The observations on plant height, panicle length, panicle bearing tillers per hill and number of filled grains per panicle were recorded from five randomly selected plants for each entry in each replication. However, days to 50 per cent flowering and grain yield were recorded on plot basis. In contrast, observations for 1000-grain weight were obtained from a random grain sample drawn from each plot in each entry and replication. The data obtained was subjected to standard statistical procedures. Genotypic and phenotypic co-efficients of variation were computed following the methodology outlined by Burton (1952), while the estimates of heritability and genetic advance were obtained as per the procedures outlined by Burton and Devane (1953), and Johnson et al. (1955), respectively. The genotypic and phenotypic correlations were calculated using the formulae suggested by Fisher and Yates (1967), while the direct and indirect contribution of each character for grain yield was estimated by path co-efficient analysis suggested by Wright (1921).

\section{RESULTS AND DISCUSSION}

The results on analysis of variance (ANOVA) for yield and yield component characters studied are presented in table 1. Highly significant mean squares due to genotypes were observed for all traits, indicating the existence of sufficient variation among the genotypes for yield and yield component characters studied in the present investigation, and therefore, there is a scope for effective selection. 
Information on mean, range, PCV, GCV, heritability, genetic advance and genetic advance in per cent of mean for yield and yield component traits are furnished in table 2. A perusal of these results revealed maximum range of variability for grain yield followed by number of filled grains per panicle. Higher phenotypic co-efficients of variation, compared to genotypic co-efficients of variation were recorded for all the traits studied in the present investigation, indicating the influence of environment. Similar findings were reported earlier by Mamta Singh et al. (2007). However, high (>20\%) phenotypic co-efficient of variation for grain yield in the present investigation was noticed to be closely and essentially associated with high genotypic co-efficient of variation for the trait, indicating the minimal influence of environment and presence of high genetic variability for the trait in the experimental material. Hence, selection on the basis of phenotype in these genotypes can also be effective for improvement of grain yield. Similar results were reported earlier by Mishra and Verma (2002) and Hasib et al. (2004). However, moderate (10-20\%) genotypic and phenotypic coefficients of variation were recorded in the present study for days to 50 per cent flowering, number of filled grains per panicle and 1000 grain weight. These results are in conformity with the findings of Bornane et al. (2014) for days to 50 per cent flowering and 1000 grain weight. In contrast, low $(<10 \%)$ estimates of genotypic and phenotypic coefficients of variation were observed in the present study for plant height, panicle bearing tillers per hill and panicle length, indicating low variability for these characters in the present experimental material and therefore little scope for improvement of these traits. Similar findings were reported earlier by Satish et al. (2003) for plant height.

High ( $>60 \%$ ) estimates of heritability were recorded for days to 50 per cent flowering, plant height, panicle length, 1000-grain weight and grain yield in the present investigation, while moderate heritability (30-60\%) was observed for panicle bearing tillers per hill and number of filled grains per panicle (Table 2). These results are in conformity with the reports of Idris et al. (2013) for 1000-seed weight and plant height; Bisne et al. (2009) for ear bearing tillers per hill; Dhanwani et al. (2013) for days to 50 per cent flowering; and Kundu et al. (2008) for grain yield per plant.

A perusal of the results on genetic advance revealed high values ( $>20 \%)$ for days to 50 per cent flowering, number of filled grains per panicle and grain yield. The estimates of genetic advance in per cent of mean was also high ( $>20 \%)$ for days to 50 per cent flowering, number of filled grains per panicle, 1000 grain weight and grain yield. These results are in conformity with the findings of Babu et al. (2012) for number of filled grains per panicle; and Dhanwani et al. (2013) for 1000 grain weight and grain yield per plant. In contrast, moderate (10-20\%) estimates of genetic advance were noticed in the present study for plant height. Similar results were reported by Babu et al. (2012). Further, low $(<10 \%)$ estimates of genetic advance were recorded in the present investigation for panicle bearing tillers per hill, panicle length and 1000-grain weight. Low $(<10 \%)$ estimates of genetic advance as per cent mean were also noticed for panicle bearing tillers per hill and panicle length in the 
present investigation. These results are in conformity with the findings of Seyoum et al. (2012).

High heritability coupled with high genetic advance as per cent mean was recorded for days to 50 per cent flowering, 1000-grain weight and grain yield per plant indicating that the high heritability observed is due to additive gene effects and selection may be effective for these characters. Similar observations were reported by Adilakshmi and Girijarani (2012) for 1000-seed weight and Madhavilatha et al. (2005) for grain yield per plant. On contrary, high heritability coupled with moderate genetic advance in per cent of mean was observed for plant height indicating the role of both additive and non-additive gene effects for control of the characters. The results are in conformity with the reports of Seyoum et al. (2012). However, panicle length had recorded high heritability coupled with low genetic advance in per cent of mean in the present investigation, which is similar to the findings of Singh et al. (2012). Further, information on genetic variation along with heritability and genetic advance estimates has been reported to give a better idea about the efficiency of selection (Burton, 1952). In the present study, high GCV and PCV coupled with high heritability and high genetic advance in per cent of mean were observed for grain yield indicating the pre-ponderance of additive gene action and therefore scope for improvement of the trait through selection. Similar results were reported earlier by Mohana Krishna et al. (2009).

The genotypic and phenotypic correlations for yield and yield components are presented in table 3. A perusal of these results revealed phenotypic and genotypic correlations to be of similar direction and significance. However, genotypic correlations had recorded a higher magnitude compared to phenotypic correlations indicating the masking effect of environment. Similar results were reported by Madhavilatha et al. (2005). Further, grain yield per plant was observed to be positively and significantly associated with panicle bearing tillers per hill and number of filled grains per panicle indicating an increase in grain yield with an increase in these characters. Therefore, priority should be given to these traits, while making selection for yield improvement. The findings are in agreement with the reports of Manikaminnie et al. (2013) for panicle bearing tillers per hill and Sudharani et al. (2013) for number of filled grains per panicle. On the contrary, non-significant association was noticed for grain yield with days to 50 per cent flowering, plant height, panicle length and 1000-grain weight. The findings are in consonance with the reports of Yadav et al. (2010).

Studies on inter-character associations for yield components revealed significant and positive association of plant height with panicle length. The results are in agreement with the reports of Manikyminnie et al. (2013). However, significant and negative inter-character associations were observed for panicle bearing tillers per hill and number of filled grains per panicle; and number of filled grains per panicle with 1000 -seed weight, probably due to competition for a common 
possibility, such as nutrient supply. The results are in conformity with the reports of Panwar et al. (2007).

Path co-efficient analysis provides an effective means of finding out the direct and indirect causes of association and presents a critical examination of the specific forces acting to produce a given correlation and also measures the relative importance of each causal factor. Hence, the study of direct and indirect effects of yield components on grain yield per plant was undertaken in the present investigation and the results obtained are presented in Table 4. A perusal of these results on path co-efficients for yield and yield components revealed genotypic and phenotypic path co-efficients to be of similar direction and magnitude. Further, the genotypic path coefficients were observed to be of higher magnitude, compared to phenotypic path coefficients indicating the masking effect of environment. The results also revealed high residual effect for both phenotypic (0.6774) and genotypic (0.6624) path coefficients, respectively, indicating that variables studied in the present investigation explained only about 33 (phenotypic) and 34 (genotypic) per cent of the variability in yield and therefore, other attributes besides the characters studied are contributing for grain yield per plant. The results also revealed high ( $>0.30)$ direct effects of panicle bearing tillers per hill, number of filled grains per panicle, days to 50 per cent flowering, 1000-grain weight and plant height on grain yield per plant. High positive direct effect of panicle bearing tillers per hill (Manikyaminnie et al., 2013); and number of filled grains per panicle (Parvathi et al., 2011) on grain yield were also reported earlier. These traits had also recorded highly significant and strong positive association with grain yield per plant. High direct effects of these traits therefore appear to be the main factor for their strong association with grain yield per plant. Hence, these traits should be considered as important selection criteria in all rice improvement programmes and direct selection for these traits is recommended for yield improvement. The results are in conformity with the findings of Meena Kumari et al. (2011). Further, days to 50 percent flowering, plant height and 1000-grain weight had also recorded high positive direct effects on grain yield per plant. The results are in consonance with the findings of Seyoum et al. (2012) for days to 50 percent flowering; and Adilakshmi and Girijarani (2012) for plant height and 1000seed weight. However, their association with grain yield per plant was noticed be non-significant in the present investigation indicating the need for adoption of restricted simultaneous selection model to nullify the undesirable indirect effects and make use of the high direct effects (Singh and Kakar, 1977). In contrast, high negative direct effect on grain yield per plant was recorded by panicle length. However its association with grain yield per plant was observed to be non-significant indicating the indirect effect of the trait on grain yield per plant through other characters. The findings are in conformity with the reports of Manikyaminnie et al. (2013).

\section{CONCLUSION}

Results of the present investigation on variability, heritability and genetic advance indicated a scope for improvement of grain yield through selection. Further, 
studies on character association and path co-efficients revealed the importance of panicle bearing tillers per hill and number of filled grains per panicle as selection criteria for effective yield improvement. The study also indicated the need for balanced selection in light of negative association of panicle bearing tillers per hill with number of filled grains per panicle; and number of filled grains per panicle with 1000 -grain weight in crop yield improvement programmes.

\section{REFERENCES}

Adilakshmi, D. and Girijarani, M. 2012. Variability, character association and path analysis in rice under submergence. Crop Research, 44(1 and 2): 146-151

Babu, V. R., Shreya. K., Kuldeep Singh Dangi, Usharani, G. and Nagesh, P. 2012. Genetic variability studies for qualitative and quantitative traits in popular rice (Oryza sativa L.) hybrids of India. International Journal of Scientific and Research Publications, 2(6): 15

Bisne, R., Sarawgi, A. K. and Verulkar, S.B. 2009. Study of heritability, genetic advance and variability for yield contributing characters in rice. Bangladesh Journal of Agricultural Research, 34(2); 175-179

Bornare, S. S., Mittra, S. K. and Mehta, A. K. 2014. Genetic variability, correlation and path analysis of floral, yield and its component traits in CMS and restorer lines of rice (Oryza sativa 1.). Bangladesh Journal of Botany, 43(1): 45-52

Burton, G. W. 1952. Quantitative inheritance in grasses. Proceedings, $6^{\text {th }}$ grassland Congress Journal 1: 277-81

Burton, G. W and Devane, E. H. 1953. Estimating heritability in tall fescue (Festuca arundinaceae) from replicated clonal material. Agronomy Journal, 45: 478-481

Dhanwani, R. K., Sarwgi, A. K., Akashsolanki and Jitendrakumartiwari. 2013. Genetic variability analysis for various yield attributing and quality traits in rice (Oryza sativa L.). The Bioscan, 8(4):1403-1407

Fisher, R. A. and Yates, F. 1967. Statistical tables for biological, agricultural and medical research. Six Edition Oliver Boyes Ltd. Edinburgh.

Hasib K. M, Ganguli P. K. and Kole P. C. 2004. Evaluation of the performance of advanced generation lines of mutant x Basmati crosses of scented rice. Journal of International Academicia, 8(1): 7-10

Idris, A. E and Mohamed, K. A. 2013. Estimation of genetic variability and correlation for grain yield components in rice (Oryza sativa L.). Global Journal of Plant Ecophysiology, 3 (1):1-6

Johnson, H. W., Robinson, H. F. and Comstock, R. E. 1955. Estimation of genetic and environmental variability in soybean. Agronomy Journal, 47:314-318

Kundu, A., Senapati, B. K., Bakshi, A and Mandal, G. S.2008. Genetic variability of panicle characters in tall indica aman rice. Oryza, 45(4): 320-323

Madhavilatha, L., Reddi Sekhar, M., Suneetha, Y and Srinivas, T. 2005. Genetic variability, correlation and path analysis for yield and quality traits in rice (Oryza sativa L.). Research on Crops, 6 (3): 527-534 
Mamta Singh, Kumar, K and Singh, R.P. 2007. Study of co-efficient of variation, heritability and genetic advance in hybrid rice. Oryza, 44 (1): 160-162

Manikyaminnie, C., Dayakar reddy, T and Surendra Raju, Ch. 2013. Correlation and path analysis for yield and its components in rice (Oryza sativa L.). The Journal of Research ANGRAU, 41(1): 132-134

Meena Kumari, K. Seetha Ramaiah. K. V., Satyanarayana, V. and Sreekanth, B. 2011. Correlation and path co-efficient analysis in rice. The Andhra Agricultural Journal, 58 (4): 434-438.

Mishra L. K. and Verma, R. K. 2002. Genetic variability for quality and yield traits in non segregating populations of rice (Oryza sativa L.). Plant Archives, 2(2): 251-256

Mohana Krishna, D., Reddy, D. M., Reddy, K. H. P and Sudhakar, P. 2009. Character association and interrelationship of yield and quality attributes in rice (Oryza sativa L.). The Andhra Agricultural Journal, 56(3): 298-301

Panwar, L. L and Mashiat Ali, 2007 Correlation and path analysis of yield and yield components in transplanted rice. Oryza, 44(2): 115-120

Parvathi, P. S., Satyanarayana Rao, V., Lal Ahmed, M and Anil Kumar, P. 2011. Correlation and path analysis of yield and quality attributes in rice. The Andhra Agricultural Journal, 58(3): 310-314

Satish, Y., Seetha Ramaiah, K. V., Sree Rama Reddy, N. and Naidu, T. C. M. 2003. Genetic variability, heritability and Genetic advance in scented rice (Oryza sativa L.). The Andhra Agricultural Journal, 50 (1\&2): 24-26

Seyoum, M., Sentayehualamerewandkassahun Bantte. 2012. Genetic variability, heritability correlation coefficient and path analysis for yield and yield related traits in upland rice (Oryza sativa L.). Journal of Plant Sciences, 7(1):13-22

Singh, P. K., Dhakad, B. K., Singh, H. B. and Singh, A. K. 2012. Genetic variability and association analysis in rice (Oryza sativa L.) treated with trichoderma harzianum. Crop Research, 44(1\&2): 141-145

Singh, R. K. and Kakar, S. N. 1977. Control on individual trait means during index selection. Proceedings of third Congress. SABRAO (Canberra), 3: 22-25

Sudharani, M., Raghava Reddy, P., Hariprasad Reddy, G and Surendra Raju, Ch. 2013. Correlation and path coefficient analysis for yield and physiological attributes in rice (oryza sativa L.) hybrids under saline soil conditions. The Journal of Research ANGRAU, 41(1): 105-108

Wright, S. 1921. Correlation and causation. Journal of Agricultural Research, 20: 257-287

Yadav, S. K., Suresh, B. G., Praveen Pandey and Binod Kumar 2010. Assessment of genetic variability, correlation and path association in rice (Oryza sativa L.). Journal of BioScience, 18:1-8. 
Table 1. Analysis of variance (ANOVA) for yield and yield components in rice

\begin{tabular}{l|c|c|c|c|c|c|c|c}
\hline $\begin{array}{c}\text { Source of } \\
\text { variation }\end{array}$ & $\begin{array}{c}\text { Degrees } \\
\text { of } \\
\text { freedom }\end{array}$ & $\begin{array}{c}\text { Days to 50 } \\
\text { percent } \\
\text { flowering }\end{array}$ & $\begin{array}{c}\text { Plant } \\
\text { height }\end{array}$ & $\begin{array}{c}\text { Panicle } \\
\text { bearing } \\
\text { tillers hill } \\
\mathbf{1}\end{array}$ & $\begin{array}{c}\text { Panicle } \\
\text { length }\end{array}$ & $\begin{array}{c}\text { Number of } \\
\text { filled grains } \\
\text { per panicle }\end{array}$ & $\begin{array}{c}\mathbf{1 0 0 0} \\
\text { grain } \\
\text { weight }\end{array}$ & $\begin{array}{c}\text { Grain yield } \\
\text { Replications }\end{array}$ \\
\hline & 2 & 0.25 & 6.73 & 0.20 & 0.75 & 680.60 & 0.44 & 77801.00 \\
Genotypes & 72 & $345.68^{* *}$ & $261.35^{* *}$ & $1.43 * *$ & $5.39 * *$ & $2853.53 * *$ & $43.81^{* *}$ & $7702179.00 * *$ \\
Error & 144 & 1.26 & 13.29 & 0.33 & 0.70 & 543.56 & 1.47 & 90489.73 \\
\hline
\end{tabular}

*, ** Significant at $5 \%$ and $1 \%$ levels, respectively

Table 2. Estimates of variability and genetic parameters for yield and yield components in rice

\begin{tabular}{|c|c|c|c|c|c|c|c|c|}
\hline \multirow[t]{2}{*}{ Character } & \multirow[t]{2}{*}{ Mean } & \multicolumn{2}{|c|}{ Range } & \multicolumn{2}{|c|}{$\begin{array}{c}\text { Co efficient of variation } \\
(\%)\end{array}$} & \multirow{2}{*}{$\begin{array}{c}\text { Per cent } \\
\text { Heritabilit } \\
\mathbf{y}\end{array}$} & \multirow{2}{*}{$\begin{array}{c}\text { Genetic } \\
\text { advance } \\
(\%)\end{array}$} & \multirow{2}{*}{$\begin{array}{c}\text { Genetic } \\
\text { advance in } \\
\text { per cent of } \\
\text { mean }\end{array}$} \\
\hline & & Minimum & Maximum & $\begin{array}{c}\text { Genotypic } \\
\text { (GCV) }\end{array}$ & $\begin{array}{l}\text { Phenotypic } \\
\quad \text { (PCV) }\end{array}$ & & & \\
\hline $\begin{array}{l}\text { Days to } 50 \text { per cent } \\
\text { flowering }\end{array}$ & 103.90 & 85.00 & 128.00 & 10.31 & 10.36 & 98.0 & 21.95 & 21.12 \\
\hline Plant height (cm) & 114.20 & 90.10 & 140.70 & 7.96 & 8.57 & 86.0 & 17.18 & 15.22 \\
\hline Panicle bearing tillers hill ${ }^{-1}$ & 9.98 & 8.80 & 12.30 & 6.10 & 8.38 & 52.85 & 0.91 & 9.11 \\
\hline Panicle length $(\mathrm{cm})$ & 23.81 & 19.20 & 27.00 & 5.25 & 6.30 & 69.33 & 2.13 & 8.94 \\
\hline $\begin{array}{l}\text { Number of filled grains } \\
\text { panicle }^{-1}\end{array}$ & 185.43 & 127.10 & 264.00 & 14.96 & 19.54 & 58.0 & 43.76 & 23.60 \\
\hline 1000-grain-weight (g) & 21.27 & 14.03 & 30.10 & 17.66 & 18.56 & 90.0 & 7.36 & 34.61 \\
\hline Grain yield (Kg ha $\left.{ }^{-1}\right)$ & 6314.32 & 2604.17 & 10570.00 & 25.22 & 25.67 & 96.0 & 3224.31 & 51.06 \\
\hline
\end{tabular}


Table 3. Phenotypic $\left(r_{p}\right)$ and Genotypic $\left(r_{g}\right)$ correlation co-efficients for yield and yield components in rice

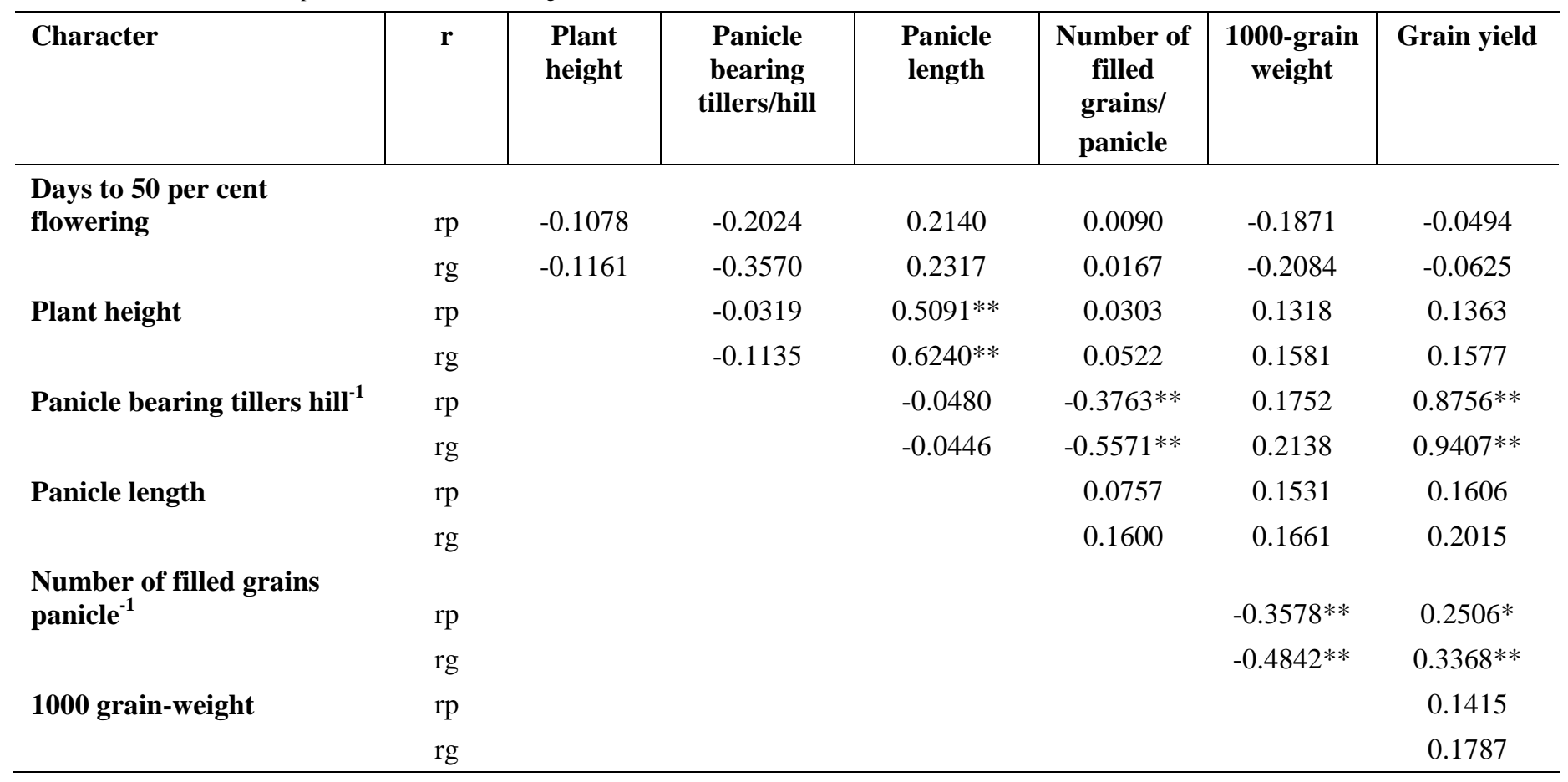

*, ** Significant at $5 \%$ and $1 \%$ levels, respectively 
Table 4. Phenotypic (P) and Genotypic (G) path co-efficients for yield and yield components in rice

\begin{tabular}{|c|c|c|c|c|c|c|c|c|}
\hline Character & & $\begin{array}{c}\text { Days to } 50 \\
\text { per cent } \\
\text { flowering }\end{array}$ & Plant height & $\begin{array}{c}\text { Panicle } \\
\text { bearing } \\
\text { tillers/hill }\end{array}$ & $\begin{array}{l}\text { Panicle } \\
\text { length }\end{array}$ & $\begin{array}{c}\text { Number of } \\
\text { filled } \\
\text { grains/ } \\
\text { panicle }\end{array}$ & $\begin{array}{l}\text { 1000- grain } \\
\text { weight }\end{array}$ & Grain yield \\
\hline \multirow{2}{*}{$\begin{array}{l}\text { Days to } 50 \text { per cent } \\
\text { flowering }\end{array}$} & $\mathbf{P}$ & 0.4371 & 0.0058 & -0.1877 & 0.0028 & -0.2013 & -0.1061 & -0.0494 \\
\hline & $\mathbf{G}$ & 0.5001 & -0.009 & -0.186 & 0.0169 & -0.2834 & -0.1011 & -0.0625 \\
\hline \multirow[t]{2}{*}{ Plant height } & $\mathbf{P}$ & 0.0579 & 0.3537 & -0.2323 & -0.0066 & -0.0045 & -0.0319 & 0.1363 \\
\hline & G & 0.0464 & 0.3779 & -0.2149 & 0.0404 & -0.1108 & 0.0186 & 0.1577 \\
\hline \multirow{2}{*}{$\begin{array}{l}\text { Panicle bearing } \\
\text { tillers/hill }\end{array}$} & $\mathbf{P}$ & 0.1087 & -0.0017 & 0.6895 & -0.0006 & 0.0317 & 0.048 & $0.8756^{* *}$ \\
\hline & $\mathbf{G}$ & 0.5429 & -0.3088 & 0.7311 & -0.2929 & 0.1149 & 0.1535 & $0.9407 * *$ \\
\hline \multirow[t]{2}{*}{ Panicle length } & $\mathbf{P}$ & 0.1149 & 0.0273 & 0.1006 & -0.3129 & -0.0112 & 0.2419 & 0.1606 \\
\hline & $\mathbf{G}$ & 0.1341 & 0.1486 & -0.0059 & -0.3647 & -0.033 & 0.3224 & 0.2015 \\
\hline \multirow{2}{*}{$\begin{array}{l}\text { Number of filled grains/ } \\
\text { panicle }\end{array}$} & $\mathbf{P}$ & -0.209 & 0.0116 & -0.0007 & -0.001 & 0.5477 & -0.098 & $0.2506^{*}$ \\
\hline & G & -0.0067 & 0.0041 & -0.1731 & 0.0103 & 0.6063 & -0.1052 & $0.3368 * *$ \\
\hline \multirow[t]{2}{*}{ 1000-grain weight } & $\mathbf{P}$ & 0.2079 & 0.0071 & 0.0017 & -0.5002 & 0.0528 & 0.3740 & 0.1415 \\
\hline & $\mathbf{G}$ & 0.0034 & 0.0108 & 0.0002 & -0.2213 & 0.0009 & 0.3847 & 0.1787 \\
\hline
\end{tabular}

*, ** Significant at $5 \%$ and $1 \%$ levels, respectively;

Residual effect $($ Phenotypic $)=0.6774 ;$ Residual effect $($ Genotypic $)=0.6624$; Diagonal values $=$ Direct effects; Off-Diagonal values $=$ Indirect effects 